\title{
Occipital Neuralgia with Atypic Symptoms: A Case Report
}

\author{
Atipik Özellikli Semptomatik Oksipital Nevralji Olgusu \\ Gökçen Gözübatık-Çelik, Eser Buluş, Derya Uluduz, Baki Göksan \\ İstanbul University Faculty of Medicine, Department Of Neurology, İstanbul, Turkey
}

\begin{abstract}
Summary
Cranial neuralgia is a rare form of headache disorders characterized with transient and unilateral attacks. Inflamatuar diseases and cervical compression are amongst the most common etiological factors even so idiopathic forms might be observed. International Classification of Headache Disorders (ICHD-2) made the classification of cranial neuralgias in 18 different groups. Occipital neuralgia, being a subgroup of cranial neuralgies, is a headache that involves anatomically at major, minor or third occipital nerve areas sometimes accompanying with sensory deficits or dysesthesia. Occipital neuralgia includes aching burning or throbbing headache that is often unilateral and continuous with intermittent shocking and shooting pain on the occipital nerve area. Patients with occipital neuralgia can be divided into those with structural causes and those with idiopathic causes. Structural lesions are cervical disc diseases, trauma, compression of the cervical discs. Tumors rarely metastasize to the paravertebral region and compression of the cervical nerve roots may result in occipital neuralgia. Our aim is to present a case with late onset medical refractory occipital neuralgia due to metastatic prostate cancer, emphasizing that relevant medical history should alert clinicans to the possibility of metastasis causing occipital neuralgia. (Turkish Journal of Neurology 2014; 20:135-137)
\end{abstract}

Key Words: Occipital neuralgia, malignancy, headache

Conflict of interest: The authors reported no conflict of interest related to this article.

\section{Özet}

Oksipital nevralji, büyük ve küçük oksipital sinirlerin bulunduğu arka oksipital bölgede hissedilen paroksismal bir baş ağrısıdır. Ağrı sıklıkla unilateral, zaman zaman şiddetlenerek elektrik çarpmasına benzer özellik gösteren, sürekli yanıcı-batıcı karakterdedir. Oksipital sinir alanı üzerine bası ile ağrı tetiklenir ve ağrıya duyarlılık eşlik edebilir. Oksipital nevralji sıklıkla idyopatik nedene bağlı olmakla birlikte nadiren enfeksiyonlar, osteoartrit veya vaskülit gibi enflamatuar hastalıklar, kök veya sinir basıları, travma, diyabet veya gut gibi sistemik hastalıklar ve C2-C3 sinir kökünü etkileyen tümörler gibi sekonder nedenlere bağlı olarak da ortaya çıkabilir. Özellikle atipik klinik sergileyen oksipital nevralji olgularında sekonder nedenler göz önünde bulundurulmalıdır.

Bu bağlamda, ileri yaşta yeni başlayan ve medikal tedavilere dirençli bir oksipital nevralji olgusunu sunarak atipik olgularda ayrıntılı etiyolojik araştırmanın gerekliliğini vurgulamayı amaçladık. (Türk Nöroloji Dergisi 2014; 20:135-137)

Anahtar Kelimeler: Oksipital nevralji, malignite, baş ă̆rısı

Çıkar çatışması: Yazarlar bu makale ile ilgili olarak herhangi bir çıkar çatışması bildirmemişlerdir.

\section{Introduction}

Cranial neuralgies are a rare form of headaches that is divided under 18 different groups according to the International Headache Classification. It is characterized by transient and unilateral attacks. Occipital neuralgia, is a subgroup of neuralgia that is accompanied by sensory deficit or dysesthesia on the major, minor or third occipital nerve areas. It can be idiopathic as well as caused by structural lesions. Among such structural lesions are cervical disk compression, cervical disk disorders, tumors and trauma. Tumors rarely metastasize to the paravertebral region and compression of the cervical nerve roots may result in occipital neuralgia.

In this context, our aim is to present a case with late onset medical refractory occipital neuralgia due to metastatic prostate cancer, emphasizing that relevant medical history should alert clinicians to the possibility of metastasis causing occipital neuralgia. 


\section{Case}

Seventy-five years old male patient came to our clinic with severe headache. He described that his headaches started after the coronary bypass surgery he had 4 months ago, starting rather sporadically at first but getting more frequent over the following weeks. The pain affected mostly left occipital region about 2-3 times a day, occurring in a sharp, transient, stabbing fashion. The patient also complained about mild pain on the occipital region triggered or exacerbated by touch or massaging. The patient was diagnosed with occipital neuralgia $(\mathrm{ON})$ based on his clinical complaints. Before coming to our clinic, the patient previously consulted in different clinics and was given non-steroid analgesics such as naproxen and ibuprofen as well as gabapentin without noticeable improvement. There was no other remarkable finding in his medical history and familial history. His otherwise normal neurological examination confirmed that the pain was triggered by touching the back of the neck and that his neck mobility was remarkably constrained.

Despite the ordinary neurological exam, secondary causes in etiology were considered given the late onset headache with an atypical localization and gender. For that purpose, cervical contrast magnetic resonance imaging (MR) was performed. This showed multiple bone metastases in the cervical region (Figures 1, 2). In order to detect the primary lesions the patient was referred to the oncology clinic with diagnosis of ON secondary to metastatic malign lesions, and was later diagnosed with primary prostate adenocarcinoma.

\section{Discussion}

Occipital neuralgia is typically idiopathic but it may also present due to secondary conditions (1). The diagnostic criteria by International Headache Society include: "Paroxysmal stabbing pain, with or without persistent aching between paroxysms, in the distribution(s) of the greater, lesser and/or third occipital nerves", tenderness on the affected nerves and temporary relief of pain with the blockage of the affected nerve (2). Temporary relief of the symptoms with the anesthetic block of the occipital nerve can support the diagnosis $(1,2)$. Among the secondary etiologies affecting cervical region, infectious conditions such as herpes zoster, neurosyphillis; inflammatory conditions such as osteoarthritis, myositis and fibrositis; vasculitides such as temporal arteritis; demyelinating diseases such as multiple sclerosis; systemic diseases such as arteriovenous malformations in craniocervical junction, Chiari malformation, trauma, gastrointestinal system tumor metastases, diabetes and gout; discopathies causing root or nerve compression; and primary and/ or secondary tumors of bone or cartilage affecting C2-C3 nerve root ganglia can be considered $(3,4,5,17)$. In ON manifestations due to lesions capable of forming masses, such as Shwannom osteochondroma and artrosis, the intensity of the pain increases with neck motion due to mass effect and increase over time while being irresponsive to symptomatic treatments $(14,15,16,17)$. In that context, treatment unresponsiveness and massage induced exacerbation, should suggest the differential diagnosis for cervical region metastases among the secondary etiologies in an older cases with ON.

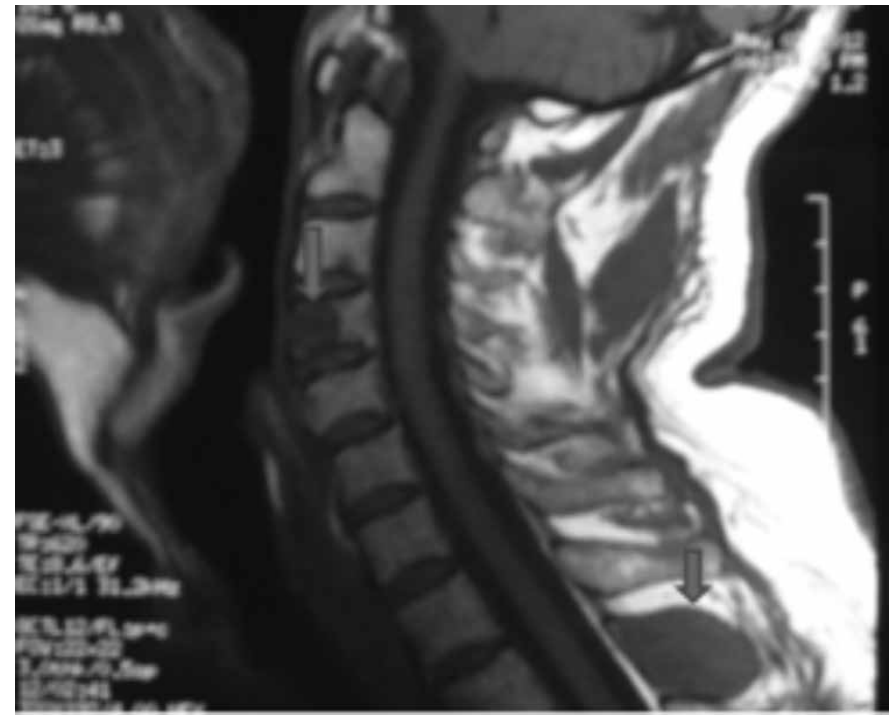

Figure 1. T1 sagittal section of cervical MR showing findings compatible with bone metastasis on the $4^{\text {th }}$ vertebra

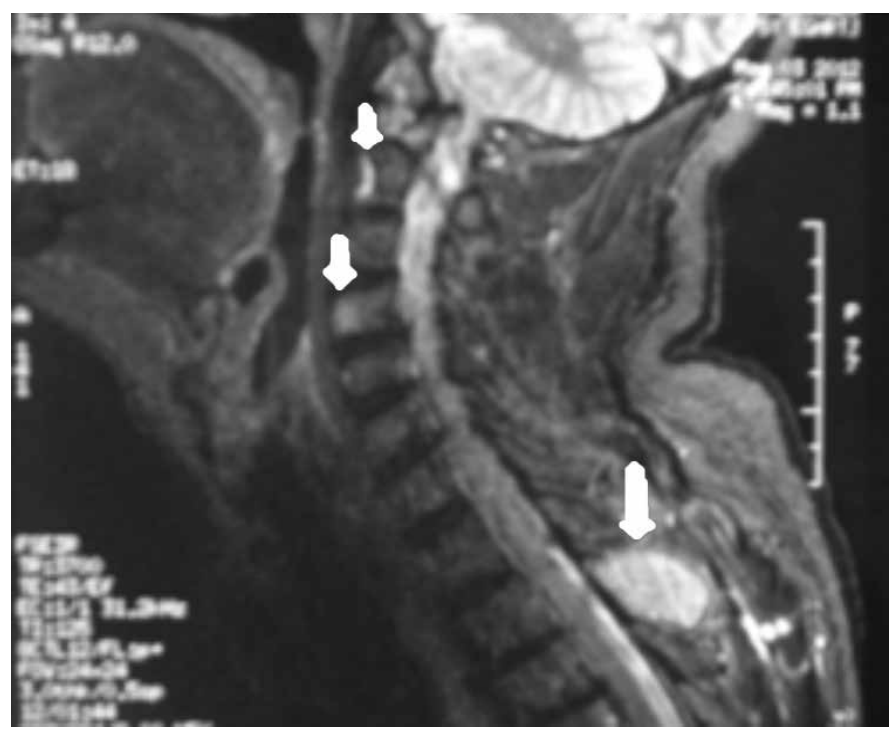

Figure 2. T2 sagittal section of cervical MR showing multiple bone metastases

Studies have shown that extradural lesions constitute more than $95 \%$ of all spinal lesions and that spinal metastases are frequently seen between ages 40 and 65 . These metastases were $60-80 \%$ thoracic, $15-30 \%$ lumbar and less than $10 \%$ cervical (12). The cervical region metastasis seen in our case was important due to its rarity and due to being the atypical manifestation of an existing prostate cancer presenting clinical symptoms.

Bone metastases are often detected as lung, prostate, breast and hematopoietic organ malignities, especially in spinal involvements $(12,18)$. In addition, it is known that esophagus carcinoma, ocular melanoma (a rare form of melanomas), facet arthropathy, and certain infections such as tuberculosis may cause bone metastasis and present with neck pain $(5,7,9,10,11,12)$. In diagnosis, contrast MR targeting spinal region is crucial. Bone scintigraphy is also an important 
diagnostic method in detecting the primary tumors of the bone such as osteoid osteoma. The source of the bone metastases detected in our patient's cervical imaging was prostate cancer, reported in the literature as the second most common cause of bone metastasis.

Depending on the etiology, the treatment of ON entails oral analgesics, anticonvulsants, cervical traction, electrical nerve stimulation, local analgesic injection or neurolytic agents as drug treatment; decompression of minor or major occipital nerve, dorsal rami or $\mathrm{C} 1-\mathrm{C} 3$ root ganglia or lesion resection as surgical intervention $(19,20,21,22,23)$.

In conclusion, we aimed to emphasize the importance of considering secondary etiologies and employing etiology-specific imaging techniques in atypically presenting occipital neuralgia starting at an old age.

\section{References}

1. Moulding HD, Bilsky MH. Metastases to the craniovertebral junction. Neurosurgery 2010;66:113-118.

2. Headache Classification Subcommittee of the International Headache Society. The International Classification of Headache Disorders: 2nd edition. Cephalalgia 2004;24: 9-160.

3. Courtois AC, Collignon J, Bruyere PJ, Crielaard JM, Kaux JF. Single cervical metastasis of breast cancer. Rev Med Liege 2011;66:285-287.

4. Sierra-Hidalgo F, Ruíz J, Morales-Cartagena A, Martínez-Salio A, Serna Jde L, Hernández-Gallego J. Infiltrative cervical lesions causing symptomatic occipital neuralgia. Cephalalgia 2011;31:1493-1496.

5. Kanai Y, Matsuda M, Iwanaga T, Hashimoto S, Maeda Y, Kanamaru A, Itagaki $\mathrm{N}$. Diffuse large B-cell lymphoma presenting with hypoglossal nerve palsy and great occipital neuralgia. Rinsho Ketsueki 2009;50:113-115.

6. Hoppenfeld JD . Cervical facet arthropathy and occipital neuralgia: headache culprits. Pain Pract 2010;10:137-144.
7. Bartels RH, van der Linden YM, van der Graaf WT. Spinal Extradural Metastasis: Review of Current Treatment Options CA. Cancer J Clin 2008;58:245-259.

8. Go SW1, Lee HY, Lim CH, Jee WH, Wang YP, Yoo IR, Kang JY. Atypical Disseminated Skeletal Tuberculosis Mimicking Metastasis on PET-CT and MRI. Intern Med 2012; 51(20): 2961-2965.

9. Lewin J, Hugel H, Sharma ML. Percutaneous cervical cordotomy for noncancer pain in a patient with terminal esophageal carcinoma. J Clin Neurosci 2012;19:610-611.

10. Shakur SF, Takagi I, Lukas RV, Chmura S, Gajewski TF, Roitberg BZ. Ocular melanoma metastasis to the cervical spine. J Spinal Disord Tech 2012;25:1-9.

11. Perrin RG, Laxton AW. Metastatic spine disease: epidemiology, pathophysiology, and evaluation of patients. Neurosurg Clin N Am 2004;15:365-373.

12. Agarawal JP, Swangsilpa T, van der Linden Y, Rades D, Jeremic B, Hoskin PJ The role of external beam radiotherapy in the management of bone metastases. Clin Oncol 2006;18:747-760.

13. Arasil E, Erdem A, Yüceer N. Osteochondroma of the upper cervical spine. A case report. Spine 1996;21:516-518.

14. Garza I. Craniocervical junction schwannoma mimicking occipital neuralgia. Headache 2007;47:1204-1205.

15. Clavel M, Clavel P. Occipital neuralgia secondary to exuberant callus formation: Case report. J Neurosurg 1996;85:1170-1171.

16. Nam-Hee Kim, Seung-Yeob Yang, Joon-Bum Koo, Sang-Wuk Jeong. Occipital Neuralgia as the Only Presenting Symptom of Foramen Magnum Meningioma. J Clin Neurol 2009;5:198-200.

17. Dubuisson D. Treatment of occipital neuralgia by partial posterior rhizotomy at C1-3. J Neurosurg 1995;82:581-586.

18. Horowitz MB, Yonas H. Occipital neuralgia treated by intradural dorsal nerve root sectioning. Cephalalgia 1993;13:354-360.

19. Joseph B, Kumar B. Gallie's fusion for atlantoaxial arthrosis with occipital neuralgia. Spine 1994;19:454-455.

20. Alexander F, Narayan R, Regis W. Haid. Occipital neuralgia secondary to hypermobile posterior arch of atlas: Case report. J Neurosurg 2001;94:276278. 